\title{
ANALISIS FAKTOR PRODUKSI TANAMAN KELAPA (Cocos nucifera) TERHADAP PENDAPATAN PETANI
}

\author{
Hamka \\ Staf Pengajar FAPERTA UMMU-Ternate,e-mail: hamka_agb@yahoo.co.id
}

\begin{abstract}
ABSTRAK
Penelitian dilaksanakan di Kabupaten Halmahera Selatan, Propinsi Maluku Utara. Pemilihan lokasi ini dilakukan secara purposive dengan pertimbangan bahwa keadaan daerah tersebut merupakan salah satu desa yang melaksanakan pengembangan usahatani Kelapa. Penelitian berlangsung dari Januari sampai dengan bulan Maret 2009. Dalam menganalisis data hubungan antara variabelvariabel yang diteliti, yakni faktor-faktor produksi usahatani Kelapa (tanah, modal dan tenaga kerja) sebagai variabel bebas $(X)$ sementara pendapatan sebagai variabel terpengaruh atau variabel tak bebas $(Y)$ maka digunakan analisis model fungsi Cobb Douglas. Hasil penelitian menunujukkan bahwa : (1) Rata-rata biaya usahatani kelapa berkisar antara $R p$ 9.911.680,00 per satuan lahan $(0,732$ ha) atau setara dengan $R p$ 13.539.574,00 per hektar, rata-rata penerimaan usahatani yang diperoleh $R p$ 17.294.664,00 per satuan lahan atau setara dengan $R p$ 23.642.892,00 per hektar, sedangkan pendapatan usahatani yang diperoleh adalah $R p$ 7.382.963,00 per satuan lahan atau setara dengan $R p$ 10.085.317,00 per hektar, (2). Penggunaan faktor produksi (lahan, modal dan tenaga kerja) berpengaruh nyata terhadap pendapatan petani kelapa rakyat yang ditunjukkan oleh nilai koefisien elastisitas lebih dari 1 (satu), artinya bahwa setiap perolehan satu satuan faktor produksi yang digunakan akan menyebabkan meningkatnya pendapatan yang diperoleh, (3). Lahan merupakan faktor produksi yang paling besar pengaruhnya terhadap pendapatan usahatani kelapa dibandingkan faktor produksi biaya dan tenaga kerja, hal ini dapat dilihat dari besarnya nilai elastisitas pendapatan lahan sebesar 1,899 lebih besar dari pada nilai elastisitas pendapatan modal dan tenaga kerja yang masing-masing sebesar 0,799 dan 0,20.
\end{abstract}

\section{Kata Kunci: Tanaman Kelapa, Cocos nucifera}

\section{PENDAHULUAN}

Sektor pertanian memegang peranan penting dalam struktur ekonomi nasional, karena ternyata sektor pertanian lebih tahan menghadapi krisis ekonomi dibandingkan dengan sektor lainnya. Selain itu sektor pertanian berperan dalam mencukupi kebutuhan penduduk, meningkatkan pendapatan petani, penyediaan bahan baku industri, memberi peluang usaha serta kesempatan kerja, dan menunjang ketahanan pangan nasional (Anwas Adiwilaga, 1992).

Kelapa (cocos nucifera) merupakan komoditas sosial yang pengembangannya secara tradisional turun-temurun tersebar di Nusantara, selain itu merupakan komoditi penting dan bernilai ekonomi karena dari daun, buah dan batang dapat dimanfaatkan. Maluku Utara memiliki luas areal tanaman kelapa mencapai 200.813 ha, yang seluruhnya adalah perkebunan rakyat dengan total produksi sebesar 208.518 ton.

Produk tanaman kelapa, selain untuk memenuhi kebutuhan masyarakat, juga sebagai sumber devisa negara melalui ekspor. Selain itu, komoditas ini dapat menyerap tenaga kerja yang tidak sedikit, yaitu sekitar 6,9 juta KK. Selain sebagai sumber minyak dan lemak nabati produk tanaman kelapa sebagai sumber bahan baku berbagai industri lainnya, seperti santan, kelapa segar, berbagai jenis oleo chemical, berbagai produk dari sabut dan tempurung kelapa, mempunyai prospek pasar yang baik. Dari hasil penelitian minyak kelapa khususnya VCO ternyata juga baik untuk kesehatan. Disamping itu minyak kelapa ternyata dapat dimanfaatkan untuk substitusi energi, yaitu untuk biodiesel 
maupun minyak bakar. Dengan demikian, pada sentra-sentra pengembangan kelapa sangat memungkinkan untuk mengembangkan penyediaan energi berbasis minyak kelapa.

Di Maluku Utara, komoditas kelapa hanya dimanfaatkan produk primernya saja, baik dalam bentuk kelapa segar maupun kopra dan untuk bahan baku minyak goreng. Upaya pengembangan produk dan pemanfaatan hasil samping dapat meningkatkan nilai tambah produk kelapa yang pada gilirannya akan dapat meningkatkan pendapatan petani kelapa. Demikian pula lahan di bawah pohon kelapa masih dapat dimanfaatkan dengan kegiatan diversifikasi baik dengan tanaman pangan maupun ternak. Upaya-upaya yang diperlukan untuk mengembangkan komoditas kelapa, meliputi; 1). Identifikasi status luasan lahan, produksi dan produktifitas kelapa, jenis/varietas, hama penyakit/kerusakan kelapa, potensi lahan untuk pengembangan, 2). Identifikasi nilai ekonomi kelapa dan produk turunannya,3). Deskripsi peluang investasi pengembangan kelapa dari hulu sampai dengan hilir, 4). Penyusunan strategi, kebijakan, dan program pengembangan kelapa dan produk turunannya di Maluku Utara.

Keberhasilan suatu usahatani antara lain dapat diukur dari tingkat pendapatan yang diperoleh. Pendapatan atau keuntungan usahatani adalah selisih antara penerimaan usahatani dengan biaya yang dikeluarkan (Mubyarto, 1989). Besarnya pendapatan yang diterima merupakan balas jasa untuk tenaga kerja keluarga dan modal yang dipakai dan pengelolaan dalam kegiatan usahatani.

Berdasarkan uraian diatas, maka analisis penggunaan faktor-faktor produksi pada usahatani kelapa rakyat dalam hubungannya dengan pendapatan yang dicapai per satuan waktu dan persatuan luas menarik untuk diteliti.

Penelitian ini bertujuan untuk mengetahui hubungan faktor produksi (lahan, modal dan tenaga kerja) dengan pendapatan petani kelapa dan untuk mengetahui faktor produksi mana yang berpengaruh paling besar terhadap pendapatan petani kelapa.

\section{METODE PENELITIAN}

\subsection{Lokasi, Waktu, populasi dan Sampel Penelitian}

Penelitian ini dilaksanakan di Kabupaten Halmahera Selatan, Propinsi Maluku Utara. Pemilihan lokasi ini dilakukan secara purposive dengan pertimbangan bahwa keadaan daerah tersebut merupakan salah satu daerah yang melaksanakan pengembangan usahatani kelapa. Penelitian berlangsung dari Januari sampai dengan bulan Maret 2009. Penetapan responden menurut Andi Hakim Nasution dan Ahmad Barizi (1993), dilakukan berdasarkan stratifide random sampling dari jumlah petani tebu di Lemahabang, yaitu dengan cara menetapkan responden yang diambil melalui penentuan jumlah sampel pada masing-masing strata kelompok tani, dilakukan degan menggunakan rumus :

$$
n k=\frac{P k}{P} x n
$$

Dimana :

$$
\begin{array}{ll}
\mathrm{P} & =\text { jumlah populasi } \\
\mathrm{Pk} & =\text { jumlah petani anggota kelompok ke- } \mathrm{k} \\
\mathrm{n} & =\text { jumlah sampel } \\
\mathrm{nk} & =\text { jumlah sampel kelompok ke- } \mathrm{k}
\end{array}
$$

Populasi responden diambil berdasarkan pada strata pemilikan luas lahan, yang pemilikannya cukup tersebar dan mewakili. Dari ukuran populasi diambil responden dengan menggunakan rumus TaroYamane (1967) dalam Jalaludin Rahmat (1999).

$$
n=\frac{N}{N d^{2}+1}
$$

Dimana :

$$
\begin{array}{ll}
\mathrm{n} & =\text { jumlah sampel } \\
\mathrm{N} & =\text { populasi } \\
\mathrm{d} & =\text { presisi }(10 \%)
\end{array}
$$

Pengambilan sampel dengan menggunakan rumus di atas, maka dari jumlah populasi sebanyak 62 orang dengan presisi (tingkat kekeliruan) sebesar $10 \%$ maka jumlah respondennya menjadi :

$$
n=\frac{62}{62(0,10)^{2}+1}=38,27 \approx 38
$$

Jadi dengan menggunakan angka pembulatan, maka jumlah responden dalam penelitian ini sebanyak 38 orang.

\subsection{Operasional Variabel}

Untuk memperjelas tentang pengertian dari seluruh variabel yang dituangkan ke dalam penelitian ini, maka diperlukan suatu batasan mengenai variabel tersebut yaitu sebagai berikut : 


\section{Pendapatan $(Y)$}

Merupakan penjumlahan dari nilai produk total usahatani baik dari hasil utama maupun dari

hasil sampingan dan biaya produksi selama satu tahun, diukur dalam rupiah/ha.

\section{Lahan Usahatani (XI)}

Lahan garapan pada areal usahatani sebagai obyek peneliti, adalah areal lahan yang ditanami

kelapa . Baik yang ditanam sendiri oleh pemilik lahan atauberstatus sebagai pemilik penggarap atau penyewa. Dihitung selama satu tahun, diukur dalam ha.

\section{Modal Usahatani (X2)}

Modal usahatani adalah seluruh biaya yang dikeluarkan dalam melakukan proses produksiuntuk menghasilkan satuan output. Dimana biaya produksi kelapa terdiri dari biayapemeliharaan tanaman, biaya sarana produksi dan biayaangkut.yang diukur dalam rupiah/ha.

\section{Curahan Tenaga Kerja (X3)}

Curahan tenaga kerja adalah banyaknya tenaga kerja yang digunakan dalam satu proses produksi usahatani kelapa, besarnya curahan tenaga kerja dihitung dengan HOK (Hari Orang Kerja).

\subsection{Pengolahan dan Analisis Data}

Dalam menganalisis data hubungan antara variabel-variabel yang diteliti, yakni faktor-faktor produksi usahatani kelapa (tanah, modal dan tenaga kerja) sebagai variabel bebas (X) sementara pendapatan sebagai variabel terpengaruh atau variabel tak bebas (Y) maka digunakan analisis model fungsi Cobb Douglas untuk menggambarkan hubungan fungsional antara faktor produksi dalam suatu proses produksi (Soekartawi, 1993). Model tersebut dijelaskan sebagai berikut :

$$
Y i=a \cdot X 1^{b 1} \cdot X 2^{b 2} \cdot X 3^{b 3} \cdot e^{u}
$$

Dimana :

$$
\begin{array}{ll}
\mathrm{Y}_{1} & =\text { Pendapatan petani (rupiah) } \\
\mathrm{X} 1 & =\text { Lahan Usahatani (hektar) } \\
\mathrm{X} 2 & =\text { Modal Usahatani (rupiah) } \\
\mathrm{X} 3 & =\text { Tenaga Kerja (HOK) } \\
\mathrm{a} & =\text { Besaran yang akan diduga } \\
\mathrm{b} 1-\mathrm{b} 3 & =\text { Elastistas faktor produksi } \\
\mathrm{u} & =\text { Unsur sisa (disturbance term) } \\
\mathrm{e} & =\text { Logaritma natural, } \mathrm{e}=2,718
\end{array}
$$

Agar model tersebut dapat dioperasikan, maka harus ditransformasikan dalam bentuk linier, yaitu sebagai berikut : $\log Y=\log a+b_{1} \log X_{1}+b_{2} \log X_{2}+b_{3} \log X_{3}$

Sedangkan menurut Teken (1986) dengan diketahuinya nilai elastisitas produk tersebut ( bi), maka akan diketahui pula fase pergerakan usahatani di daerah penelitian yaitu sebagai berikut :

Jika $\Sigma$ bi $=1$ Maka fungsi produksi berada pada skala usahatani dengan hasil tetap, artinya laju kenaikan produksi yang senantiasa tidak berubah meskipun dilakukan peningkatan penggunaan faktor produksi.

Jika $\Sigma$ bi $>1$ Maka fungsi produksi berada pada skala usahatani dengan hasil yang meningkat, artinya laju kenaikan produksi yang senantiasa berubah sesuai dengan pertambahan faktor produksi.

Jika $\Sigma$ bi $<1$ Maka fungsi produksi berada pada skala usahatani dengan hasil yang menurun,artinya laju kenaikan produksi yang senantiasa menurun meskipun dilakukan penambahanfaktor produksi.

\section{HASIL DAN PEMBAHASAN}

\subsection{Keadaan Sosial Ekonomi Petani Responden}

\subsubsection{Umur Petani Responden}

Hasil wawancara langsung diperoleh data mengenai umur petani responden berkisarantara 35 - 67 tahun, dengan rata-rata 51 tahun. Untuk lebih jelasnya dapat dilihat pada Tabel1.

\section{Tabel 1. Keadaan Umur Petani Responden}

\begin{tabular}{cccc}
\hline No & $\begin{array}{c}\text { Kelompok } \\
\text { Umur (tahun) }\end{array}$ & $\begin{array}{c}\text { Jumlah } \\
\text { (orang) }\end{array}$ & $\begin{array}{c}\text { Persentase } \\
(\mathbf{\%})\end{array}$ \\
\hline 1 & $35-54$ & 24 & 63,15 \\
2 & $>35$ & 14 & 36,85 \\
\hline \multicolumn{5}{c}{ Jumlah } & $\mathbf{3 8}$ & $\mathbf{1 0 0}$ \\
\hline
\end{tabular}

Tabel 1 diperoleh suatu gambaran bahwa keadaan umur petani responden sebagaianbesar $(63,15 \%)$ adalah usia produktif yaitu yang berada pada umur 35 - 54 tahun. Hal inimenunjukkan bahwa petani responden mampu untuk melaksanakan usahatani kelapa yang sedang mereka hadapi. Sedangkan petani responden yang berada pada usia tidak produktif hanya sebagian kecil yaitu $36,85 \%$ (berada pada umur $>54$ tahun). Hal ini bukan berarti tidak produktif sama sekali, tetapi aktivitasnya sudah mulai menurun sesuai dengan perjalanan umur responden, karena umur merupakan salah satu 
faktor yang berpengaruh terhadap aktivitas dalam berusahatani. Faktor usia akan mempengaruhi terhadap keadaan penyerapan motivasi teknologi dengan umur semakin tua akan semakin lambat menerima inovasi baru.

\subsubsection{Pendidikan Petani Responden}

Tingkat pendidikan responden yang dimaksud dalam penelitian ini yaitu pendidikan formalyang diterima oleh petani responden. Tingkat pendidikan diukur dengan menggunakan lamanya pendidikan yang dikatagorikan sebagai berikut: tamatan Sekolah Dasar, SekolahMenengah Pertama, Sekolah Menengah Atas atau sedejat dan Perguruan Tinggi. Untuk lebihjelasnya dapat dilihat pada Tabel 2 .

Tabel 2. Tingkat Pendidikan Petani Responden

\begin{tabular}{cccc}
\hline No & $\begin{array}{c}\text { Tingkat } \\
\text { Pendidikan }\end{array}$ & $\begin{array}{c}\text { Jumlah } \\
\text { (orang) }\end{array}$ & $\begin{array}{c}\text { Persentase } \\
(\%)\end{array}$ \\
\hline 1 & Tamatan SD & 30 & 78,95 \\
2 & Tamatan SMP & 8 & 21,05 \\
3 & Tamatan SMA & - & - \\
\hline & Jumlah & $\mathbf{3 8}$ & $\mathbf{1 0 0}$
\end{tabular}

Sumber : Data Primer Setelah di olah, 2009

Tingkat pendidikan petani responden pada umumnya masih tergolong rendah, sebagian besaradalah tamatan Sekolah Dasar 78,95\%, tamatan SMP21,05\%. Untuk lebih jelasnya dapatdilihat pada Tabel 2. Rendahnya tingkat pendidikan dikarenakan tingkat kesadaran untukmelanjutkan pendidikan ke tingkat yang lebih tinggi masih rendah, selain dipengaruhi olehkeadaan ekonomi khususnya biaya sekolah. Dengan demikian petani responden mengikuti kebiasaan orang tua mereka setelah tamat Sekolah Dasar mereka langsung kerja dalamkegiatan di sektor pertanian.

Pendidikan diharapkan

akan

mempengaruhi responden dalam menjalankan usahataninya.Pendidikan yang tinggi akan mempunyai pengetahuan dan wawasan yang lebih luas, sehingga keterbukaan dengan dunia luar semakin luas pula. Sejalan dengan pendapat Mosher A.T. (1981) dalam Mubyarto (1995), bahwa pendidikan penduduk merupakan salah satu pelancar dalam proses belajar untuk mengadopsi suatu inovasi. Dengan demikian petani akan lebih memungkinkan mudah mencari informasi baru serta mengadopsi inovasi yang telah ada dalam usaha pembaharuan usahataninya.

\subsubsection{Pengalaman Berusahatani Responden}

Pengalaman kerja responden merupakan salah satu faktor yang mempengaruhi keberhasilan usahatani di sektor pertanian khususnya dalam usahatani kelapa. Dengan belajar dari pengalaman petani akan mendapatkan pengetahuan baik teori maupun praktek untuk memperlancar kegiatan usahataninya.

Pengalaman usahatani yang dimaksud dalam penelitian ini adalah lamanya petaniresponden melaksanakan usahatani kelapa. Pada umumnya pengalaman berusahatani seseorang petani akan berbeda dengan petani lainnya. Pengalaman petani responden dalam berusahatani di daerah penelitian sebagaian besar berpengalaman antara 6 - 10 tahun sebanyak 4 orang $(10,53 \%)$, dan petani responden berpengalaman usahatani antara 11 - 16 tahun sebanyak 34 orang $(89,47 \%)$. Untuk lebih jelasnya dapat dilihat pada Tabel 3 .

Tabel 3. Pengalaman Petani Responden Dalam Berusahatani

\begin{tabular}{cccc}
\hline No & $\begin{array}{c}\text { Pengalaman } \\
\text { Responden } \\
\text { (tahun) }\end{array}$ & $\begin{array}{c}\text { Jumlah } \\
\text { (orang) }\end{array}$ & $\begin{array}{c}\text { Persentase } \\
\text { (\%) }\end{array}$ \\
\hline 1 & $1-10$ & 4 & 10,53 \\
2 & $11-16$ & 34 & 89,47 \\
\hline & Jumlah & $\mathbf{3 8}$ & $\mathbf{1 0 0}$ \\
\hline
\end{tabular}

Sumber : Data Primer Setelah di olah, 2009

Pengalaman merupakan salah satu faktor yang menentukan keberhasilan dalam berusatani, karena pengalaman masa lalu seseorang dapat berpengaruh terhadap pekerjaan yang sekarangdilakukan. Hal ini berkaitan dengan resiko kegagalan usahatani. Mengenai lamanya pengalaman yang berbeda antar reponden turut berpengaruh dalam menjalankanusahataninya. Petani yang berpengalaman lebih lama akan lebih mengetahui situasi dankondisi usahatani yang dihadapi, sehingga keberhasilan ataupun kegagalan dimasa lampaudapat dijadikan tolok ukur dalam melaksanakan usahatani yang lebih baik.

\subsubsection{Tanggungan Keluarga Responden}

Tanggungan keluarga responden yaitu banyaknya orang yang harus dibiayai oleh kepala keluarga sebagai pencari nafkah, bukan berdasarkan banyaknya anak. Jumlah tanggungan keluarga berkaitan erat dengan pendapatan dan pengeluaran keluarga, semakin banyak tanggungan keluarga, maka semakin besar pengeluaran keluarga tersebut. Dengan demikianpetani sebagai pencari nafkah akan sungguh-sungguh dalam mengerjakan pekerjaannya.Jumlah tanggungan keluarga petani responden dapat dilihat pada Tabel 4 . 
Tabel 4. Tanggungan Keluarga Petani Responden

\begin{tabular}{cccc}
\hline No & $\begin{array}{c}\text { Pengalaman } \\
\text { Responden } \\
\text { (tahun) }\end{array}$ & $\begin{array}{c}\text { Jumlah } \\
\text { (orang) }\end{array}$ & $\begin{array}{c}\text { Persentase } \\
(\%)\end{array}$ \\
\hline 1 & $1-2$ & 5 & 13,15 \\
2 & $3-4$ & 23 & 60,52 \\
3 & $>4$ & 10 & 26,33 \\
\hline & Jumlah & $\mathbf{3 8}$ & $\mathbf{1 0 0}$ \\
\hline
\end{tabular}

Sumber : Data Primer Setelah di olah, 2009

Tabel 4 diperoleh suatu gambaran bahwa petani responden sebagian besar mempunyai tanggungan keluarga antara 3 - 4 orang per kepala keluarga, yaitu sebanyak 23 orang $(60,52 \%)$, petani responden yang mempunyai tanggungan keluarga antara 1 - 2 orang per kepala keluarga sebanyak 5 orang $(13,15 \%)$, dan petani responden yangmempunyai tanggungan lebih dari 4 orang per kepala keluarga sebanyak 10 orang $(26,33 \%)$.

Banyaknya tanggungan keluarga petani responden akan berpengaruh terhadap cepat atau lambatnya penerimaan inovasi. Umumnya petani responden yang mempunyai tanggunganlebih banyak akan lebih mudah menerima inovasi, hal ini dikarenakan terdorong olehkewajibannya untuk membiayai sejumlah orang yang menjadi tanggungannya.

\subsubsection{Luas Lahan Garapan Responden}

Luas lahan garapan petani responden di daerah penelitian berkisar 0,22 - 1,42 ha, dengan rata-rata 0,73 ha. Dari hasil penelitian diperoleh sebagian besar petani respondenmempunyai luas lahan garapan kurang dari ,62 ha yaitu sebanyak 15 orang $(39,47 \%)$, luas lahan garapan antara 0,63 - 1,03 ha sebanyak 13 orang $(34,21 \%)$, dan petani responden yang mempunyai luas lahan garapan lebih 1,04 ha sebanyak 10 orang $(26,32 \%)$. Untuk lebih jelasnya dapat di lihat pada Tabel 5 .

Tabel 5. Luas Lahan Garapan Petani Responden

\begin{tabular}{cccc}
\hline No & $\begin{array}{c}\text { Luas Lahan Garapan } \\
\text { (ha) }\end{array}$ & $\begin{array}{c}\text { Jumlah } \\
\text { (orang) }\end{array}$ & $\begin{array}{c}\text { Persentas } \\
\text { (\%) }\end{array}$ \\
\hline 1 & $0,22-0,62$ & 15 & 39,47 \\
\hline 2 & $0,63-1,03$ & 13 & 34,21 \\
\hline 3 & $1,04-1,42$ & 10 & 26,32 \\
\hline & Jumlah & $\mathbf{3 8}$ & $\mathbf{1 0 0}$ \\
\hline
\end{tabular}

Sumber : Data Primer Setelah di olah, 2009

Hatta Sastramiharja (1997) mengatakan bahwa petani dengan luas pemilikan lahan yang sempit banyak mengalami hambatan, jika dihadapkan dengan penggunaan teknologi baru. Luas lahan garapan yang sempit akan menyebabkan kecilnya pendapatan, sehingga untuk memenuhi kebutuhan akan pangan biasanya mengusahakan lahannya dengan tujuan jangka pendek dan lebih intensif tanpa memperhatikan kesesuaian dengan kemampuan lahannya.

Luas lahan garapan usahatani sering menjadi bahan pertimbangan petani dalam mengambil keputusan untuk menerima suatu inovasi, biasanya petani yang mempunyai garapan usahatani yang luas akan beranimengambil resiko dibandingkan petani yang mempunyai lahan garapan yang lebih sempit, umumnya merasa takut seandainya biaya yang dikeluarkan untuk membeli sarana produksilebih besar dibandng hasil panen yang mereka terima.

\subsection{Pembahasan}

\subsubsection{Faktor Produksi dan Pendapatan Petani}

Berdasarkan hasil perhitungan, biaya usahatani kelapa berkisar antara Rp. 2.800.512 Rp. 19.956.112, atau rata-rata sebesar Rp. 9.911.680 per satuan lahan (0,732 ha) atau setaradengan Rp. 13.539.574 per hektar. Untuk lebih jelasnya dapat dilihat pada Tabel 6 .

Tabel 6. Biaya Usahatani Kelapa

\begin{tabular}{llrr}
\hline No & Komponen Biaya & \multicolumn{2}{c}{ Biaya Usahatani (Rp) } \\
\cline { 3 - 4 } & & $\begin{array}{c}\text { Per } \mathbf{0 , 7 3 2} \\
\text { ha }\end{array}$ & Per hektar \\
\hline 1 & Biaya Tidak Tetap & & \\
& a. Sarana Produksi & 2.126 .613 & 2.905 .000 \\
& b. Tenaga Kerja & 4.419 .318 & 6.036 .886 \\
& C. Bunga Modal 12\% & 571.047 & 780.063 \\
\hline 2 & Biaya Tetap & & \\
& a. Sewa Lahan & 2.043 .200 & 2.791 .056 \\
& b. Penyusutan Alat & 366.026 & 500.000 \\
& c. Bunga Modal 16\% & 385.476 & 526.569 \\
\hline & Jumlah & $\mathbf{9 . 9 1 1 . 6 8 0}$ & $\mathbf{1 3 . 5 3 9 . 5 7 4}$ \\
\hline
\end{tabular}

Sumber : Data Primer Setelah di olah,2009

Penerimaan usahatani kelapa yang diperoleh petani berkisar antara Rp. 3.903.295 Rp. 42.923.457, dengan rata-rata sebear Rp. 17.294.664 per satuan lahan (0,732 ha) Atausetara dengan Rp. 23.624.892 per hektar. Untuk lebih jelasnya dapat dilihat pada Tabel 7

\begin{tabular}{|c|c|c|c|}
\hline \multirow[t]{2}{*}{ No } & \multirow{2}{*}{$\begin{array}{l}\text { Komponen } \\
\text { Penerimaan }\end{array}$} & \multicolumn{2}{|c|}{ Biaya Usahatani (Rp) } \\
\hline & & Per 0,732 ha & Per hektar \\
\hline 1 & Kopra & 16.496 .806 & 22.535 .000 \\
\hline 2 & Minyak Kelapa & 797.858 & 1.089 .892 \\
\hline & Jumlah & 17.294.664 & 23.624.892 \\
\hline
\end{tabular}

Sumber : Data Primer Setelah diolah, 2009 
Berdasarkan penerimaan dan biaya yang dikeluarkan, maka diperoleh pendapatan usahatani Kelapa rata-rata sebesar Rp. 7.382.963per satuan lahan (0,732 ha) atau setara dengan Rp. 10.085.317 per hektar. Untuk lebih jelasnya dapat dilihat pada Tabel 8.

Tabel 8. Rata-rata Penerimaan Usahatani kelapa Responden

\begin{tabular}{|c|c|c|c|}
\hline No & Uraian & Per 0,732 & Per hektar \\
\hline 1 & $\begin{array}{l}\text { Penerimaan } \\
\text { Usahatani }\end{array}$ & 17.292 .664 & 23.624 .892 \\
\hline 2 & Biaya Usahatani & 9.911 .680 & 13.539 .574 \\
\hline 3 & $\begin{array}{l}\text { Pendapatan } \\
\text { Usahatani }\end{array}$ & 7.382 .982 & 10.085 .318 \\
\hline 4 & $\begin{array}{l}\text { Revenue Cost Ratio } \\
(\mathrm{R} / \mathrm{C})\end{array}$ & 1.74 & 1,74 \\
\hline
\end{tabular}

\subsubsection{Pengaruh Penggunaan Faktor Produksi dengan Pendapatan Petani}

Faktor produksi yang digunakan dengan pendapatan yang dihasilkan terdapat hubungan yang erat. Hubungan tersebut dinyatakan dalam bentuk fungsi produksi. Fungsi produksi inilah yang dipergunakan untuk mengetahui hubungan antara faktor produksi dengan pendapatan usahatani. Untuk mengetahui seberapajauh hubungan antara faktor produksi yang digunakan (Xi) dengan pendapatan usahatani (Y), maka secara silmultan dilakukan dengan pengujian uji F sebagaimana terlihat pada Tabel 9.

Tabel 9. Analisis Ragam Persamaan Regresi Usahatani Kelapa

\begin{tabular}{cccccc}
\hline $\begin{array}{c}\text { Sumber } \\
\text { Regresi }\end{array}$ & DB & JK & KT & F hitung & Sig.F \\
\hline Regresi & 3 & 5,701 & 1,900 & $552,28^{*}$ & 0,000 \\
Galat & 34 & 0,117 & 0,003 & & \\
Total & 37 & 5,818 & \\
\hline Keterangan : * Berpengaruh nyata pada taraf 5\%, koefisien \\
Determinasi $\left(R^{2}\right)=0,980$
\end{tabular}

Dari hasil analisis menunjukkan bahwa nilai $\mathrm{F}_{\text {hitung }}=552,28$, dengan nilai $\mathrm{F}_{0.05}=2,88$ atau nilai Sig F lebih kecil dari nilai P 0,05. Hal ini menunjukkan bahwa faktor produksi yang digunakan sebagai peubah bebas $\left(\mathrm{X}_{\mathrm{i}}\right)$ dalam model ini secara serempak memberikan pengaruh nyata terhadap pendapatan petani kelapa sebagi peubah tidak bebas $(\mathrm{Y})$. Nilaideterminasi $\left(\mathrm{R}_{2}\right)$ sebesar 0,980 , artinya sebesar $98,00 \%$ dari varian atau simpangan-simpangan yang terjadi pada pendapatan $(\mathrm{Y})$ diterangkan oleh faktor produksi, yaitu lahan $\left(\mathrm{X}_{1}\right)$, modal usahatani $\left(\mathrm{X}_{2}\right)$ dan curahan tenaga kerja $\left(X_{3}\right)$,sedangkan sisanya ditentukan oleh faktor lain di luar variabel yang diteliti. Dari analisis ragam regresi maka diperoleh koefisien regresi faktor produksi terhadap pendapatan usahatani kelapa, sebagaimana dapat dilihat pada Tabel 10.

Tabel 10. Koefisien Regresi Faktor Produksi terhadap Pendapatan Usahatani Kelapa

\begin{tabular}{lcc}
\hline \multicolumn{1}{c}{ Peubah } & Koefisien & Regresi \\
\hline Intersep/konstanta & $\mathrm{b}_{0}$ & 7,110 \\
Luas Lahan $\left(\mathrm{X}_{1}\right)$ & $\mathrm{b}_{1}$ & 1,899 \\
Modal Usahatani $\left(\mathrm{X}_{2}\right)$ & $\mathrm{b}_{2}$ & 0,799 \\
Tenaga Kerja $\left(\mathrm{X}_{3}\right)$ & $\mathrm{b}_{3}$ & 0,220 \\
\hline
\end{tabular}

Dari data koefisien regrasi faktor produksi terhadap pendapatan usahatani kelapa, maka diperoleh persamaan regrasi sebagai berikut :

$\log Y=\log 7,110+1,899 \log X_{1}+0,799 \log$ $\mathrm{X}_{2}+0,220 \log \mathrm{X}_{3}$

Kemudian dari persamaan regresi tersebut diantilogkan menjadi fungsi Cobb Douglas, sehingga diperoleh persamaan sebagai berikut : $\mathrm{Y}=7,100 \cdot \mathrm{X}_{1}^{1,899} \cdot \mathrm{X}_{2}{ }^{0,799} \cdot \mathrm{X}_{3}{ }^{0220}$

Selanjutnya untuk mengetahui seberapa besar kontribusi masing-masing faktor terhadap pendapatan yang dicapai, maka secara parsial dilakukan dengan menggunakan uji $t$ sebagaimana dapat dilihat pada Tabel 11 .

Tabel 11. Kontribusi Masing-masing Faktor Produksi Usahatani Kelapa

\begin{tabular}{lccr}
\hline Faktor Produksi & thitung $^{*}$ & $\begin{array}{c}\mathbf{t}_{\text {Tabel }} \\
(0,05)\end{array}$ & $\begin{array}{c}\text { Elastisitas } \\
\text { Pendapatan }\end{array}$ \\
\hline Luas Lahan $\left(\mathrm{X}_{1}\right)$ & $5,252^{*}$ & 2,020 & 1,899 \\
Modal Usahatani $\left(\mathrm{X}_{2}\right)$ & $2,750^{*}$ & 2,020 & 0,799 \\
Tenaga Kerja $\left(\mathrm{X}_{3}\right)$ & $2,303^{*}$ & 2,020 & 0,220 \\
\hline Keng
\end{tabular}

Keterangan: * berbeda nyata

Tabel 11 dapat dilihat bahwa elastisitas luas lahan sebesar 1,899 memberikan kontribusi yang sangat nyata terhadap pendapatan usahatani kelapa tegalan yang dicapai, dengan nilai $t_{\text {hitung }}$ 5,252 lebih besar dari $\mathrm{t}_{0.05}, 2,020$ pada taraf nyata $5 \%$, artinya setiap penambahan luas lahan sebesar satuan unit akan memperoleh pendapatan usahatani sebesar Rp. 1,899. Besarnya elastisitas lahan menunjukkan nilai kontribusi lahan terhadap pendapatan usahatani yang diperoleh. Elastisitas lahan menunjukkan nilai yang besar terhadap pendapatan usahatani kelapa . Hal ini karena lahan merupakan faktor produksi yang utama, sehingga memberikan kontribusi yang paling besar dibandingkan dengan faktor produksi yang lain. Selama faktor produksi yang lain cukup tersedia, peningkatan faktor produksi 
melalui penambahan luas lahan akan memberikan kontribusi yang lebih besar.

Begitu pula efisiensi faktor modal usahatani sebesar 0,799 memberikan kontribusi yang nyata terhadap pendapatan usahatani kelapa yang dicapai dengan nilai $t_{\text {hitung }}$ sebesar 2,750 , lebih besar dari $\mathrm{t}_{0.05}, 2,020$ pada taraf nyata $5 \%$, artinya setiap penambahan biaya usahatani sebesar satuan unit akanmemperoleh pendapatan usahatani sebesar Rp. 0,799. Besarnya elastisitas lahan menunjukkan nilai kontribusi lahan terhadap pendapatan usahatani kelapa yang diperoleh. Elastisitas lahan menunjukkan nilai yang paling besar terhadap pendapatan usahatani kelapa.

Demikian pula dengan efisiensi faktor produksi tenaga kerja sebesar 0,220 memberikan kontribusi yang nyata terhadap pendapatan usahatani kelapa yang dicapai dengan nilai $t_{\text {hitung }}$ sebesar 2,303, lebih kecil dari $\mathrm{t}_{0.05}, 2,020$ pada taraf nyata 5\%, artinya setiap penambahan tenaga kerja sebesar satuan unit akan meningkatkan pendapatan usahatani kelapa sebesar Rp. 0,220. Besarnya elastisitas lahan menunjukkan nilai kontribusi tenaga kerja terhadap pendapatan usahatani kelapa yang diperoleh. Nilai elastisitas tersebut menunjukkan bahwa nilai faktor produksi tenaga kerja memberikan kontribusi yang lebih kecil bila dibandingkan dengan faktor produksi lahan dan biaya usahatani.

Besarnya hubungan antara masing-masing faktor produksi terhadap pendapatan petani kelapa dapat dilihat pada Tabel 12.

Tabel 12. Koefisien Korelasi Parsial Faktor Produksi Terhadap Pendapatan

\begin{tabular}{lccc}
\hline \multicolumn{1}{c}{ Faktor Produksi } & $\begin{array}{c}\mathbf{r} \\
\text { Parsial }\end{array}$ & $\mathbf{R}^{2}$ & $\begin{array}{c}\text { Sig } \\
\text { (1-tailed) }\end{array}$ \\
\hline Luas Lahan $\left(\mathrm{X}_{1}\right)$ & 0,982 & 0,964 & 0,000 \\
Modal Usahatani $\left(\mathrm{X}_{2}\right)$ & 0,981 & 0,962 & 0,000 \\
Tenaga Kerja $\left(\mathrm{X}_{3}\right)$ & 0,902 & 0,814 & 0,000 \\
\hline
\end{tabular}

ata Tabel 12, menunjukkan bahwa besarnya koefisien korelasi parsial pada lahan usahatani kelapa sebesar 0,982 , dengan nilai keofisien determinasi sebesar 0,964 atau 96,40\%. Besarnya koefisien korelasi parsial pada biaya usahatani kelapa sebesar 0,981, dengan nilai keofisien determinasi sebesar 0,962 atau 96,20\%. Sedangkan Besarnya koefisien korelasi parsial pada tenaga kerja sebesar 0,902 , dengan nilai keofisien determinasi sebesar 0,814 atau $81,40 \%$. Luas lahan mempunyai hubungan yang paling besar terhadap pendapatan usahatani kelapa. Hal ini karena lahan merupakan faktor produksi utama dalam kegiatan usahatani, sehingga kontribusi faktor produksi terhadap pendapatan usahatani kelapa lebih besar dibandingkan dengan faktor produksi biaya usahatani dan tenaga kerja.

\section{KESIMPULAN}

Berdasarkan hasil penelitian dan pembahasan yang telah diuraikan di muka, maka dapat ditarik kesimpulan, rata-rata biaya usahatani kelapa berkisar antara Rp 9.911.680,00 per satuan lahan (0,732 ha) atau setara dengan $\mathrm{Rp}$ 13.539.574,00 per hektar, rata-rata penerimaan usahatani yang diperoleh $\mathrm{Rp}$ 17.294.664,00 per satuan lahan atau setara dengan $\mathrm{Rp}$ 23.642.892,00 per hektar, sedangkan pendapatan usahatani yang diperoleh adalah $\mathrm{Rp}$ 7.382.963,00 per satuan lahan atau setara dengan Rp 10.085.317,00 per hektar. Penggunaan faktor produksi (lahan, modal dan tenaga kerja) berpengaruh nyata terhadap pendapatan petani kelapa rakyat yang ditunjukkan oleh nilai koefisien elastisitas lebih dari 1 (satu), artinya bahwa setiap perolehan satu satuan faktor produksi yang digunakan akan menyebabkan meningkatnya pendapatan yang diperoleh. Lahan merupakan faktor produksi yang paling besar pengaruhnya terhadap pendapatan usahatani dibandingkan faktor produksi biaya dan tenaga kerja, hal ini dapat dilihat dari besarnya nilai elastisitas pendapatan lahan sebesar 1,899 lebih besar dari pada nilai elastisitas pendapatan modal dan tenaga kerja yang masing-masing sebesar 0,799 dan 0,20 .

\section{DAFTAR PUSTAKA}

Andi Hakim Nasution dan Ahmad Barizi. 1993. Metode Statistika untuk Penarikan Kesimpulan. PT. Gramedia, Jakarta.

Anwas Adiwilaga. 1992. Ilmu Usahatani. Cetakan ke-III. Alumni, Bandung.

Direktorat Jenderal Pertanian dan Perkebunan. 1993. Kebijakan Menteri Pertanian Dalam Kegiatan Penyuluhan Pertanian. Departemen Pertanian. Jakarta. 
Direktorat Jenderal Bina Produksi Perkebunan. 2002. Usaha Peningkatan Produksi Kelapa. Departemen Pertanian, Jakarta.

Hatta Sastramiharja. 1997. Usaha Pembinaan Usahatani Lahan Sempit. Departemen Ekonomi Pertanian IPB, Bogor.

I. B. Teken. 1986. Metode Penelitian Sosial Ekonomi. PT. Rajawali Press, Jakarta.

Jalaludin Rachmat. 1999. Metode Penelitian Komunikasi. PT. Remaja Rosda Karya, Bandung.

Mubyarto. 1989. Pengantar Ekonomi Pertanian. Lembaga Penelitian, Pendidikan dan Penerangan ekonomi dan Sosial (LP3ES) Edisi ke-3. Jakarta.

. 1995. Pengantar Ekonomi Pertanian, Cetakan keempat. Lembaga Penelitian Pendidikan dan Penerangan Ekonomi dan Sosial (LP3ES). Jakarta.

Soekartawi. 1991. Analisis Fungsi Cobb Douglas. Teori dan Aplikasinya. Universitas Brawijaya, Malang.

Sugeng Sudiatso dan Purwono. 1996. Budidaya Tembakau, Kelapa dan Serat-seratan. Universitas Terbuka. Jakarta.

Winarno dan Birowo. 1987. Budidaya Tanaman Kelapa. Yasaguna, Jakarta. 